\title{
FREE ELECTIONS AND POLITICAL INSTABILITY IN LESOTHO
}

\author{
Richard F Weisfelder \\ Richard Weisfelder is Professor (retired) in the Department of Political Science \\ at the University of Toledo \\ email: richard.weisfelder@utoledo.edu
}

\begin{abstract}
Since 1993, Lesotho has had six free elections. Five have been followed by episodes of coercive regional diplomacy or military intervention to maintain order or sustain the elected government. Two of these interventions have occurred as Lesotho's electoral system was being transformed from a firstpast-the-post dominant party system to a mixed member proportional pattern, and a third intervention is presently underway. This essay contends that the effort to remedy the prior lack of inclusiveness in Parliament has accentuated the fissiparous proclivities within Lesotho's political culture. Following the 2012 and 2015 elections, greater fragmentation among political parties led to hung parliaments and coalition governments with minimal parliamentary majorities. This essay questions whether Staffan Lindberg's conceptual model regarding the link between the consolidation of democracy and the experience of successive free and fair elections can adequately explain Lesotho's trajectory. Remarkably, the transfers of power by Pakalitha Mosisili to Motsoahae Thomas Thabane in 2012, and by Thabane back to Mosisili in 2015, were the first such exchanges between an incumbent government and an opposition party in southern Africa during the post-liberation era. Whether this positive development might be translated into more effective governance and regard for democratic norms will be explored.
\end{abstract}

Keywords: electoral systems, proportional representation, Lesotho, SADC, coalition governments. 


\section{HISTORICAL AND REGIONAL CONTEXT OF LESOTHO'S CONSECUTIVE TRANSFERS OF POWER}

Within a three year period, Setsoto Stadium in Maseru was twice the scene where political power was peacefully transferred. In the first event, power was transferred from Lesotho's long-serving Prime Minister Pakalitha Mosisili to Motsoahae Thomas Thabane, and in the second event it was returned from Thabane to Mosisili. Each man had cobbled together a coalition government commanding a small majority of seats in the National Assembly following the 2012 and 2015 elections, respectively (Rosenberg \& Weisfelder 2013). ${ }^{1}$ The dominant Lesotho Congress for Democracy (LCD) had prevailed in the 1998, 2002, and 2007 elections. Hence the 2012 election was the first instance of an opposition victory, and the 2015 election was the second. The exchanges of pleasantries by these seasoned political rivals during their public transfers of power were hardly routine; they were regional breakthroughs.

In Africa south of the Zambezi, there had been no prior instance where the incumbent party voluntarily and peacefully transferred power to an opposition party. Among Lesotho's peers in the Southern African Development Community (SADC), the party that overturned colonial or white minority rule has prevailed in every election. New heads of government from the incumbent parties have assumed office. However, these ruling parties have yet to meet a crucial test of democracy, namely to surrender their power and the perquisites of office after an electoral defeat. This challenge is harder when the successful opposition party has previously been derided as incompetent, disloyal or worse.

Peaceful transfers of power in Lesotho may be easier in the absence of significant ethnic, religious, and ideological differences among the contesting parties. However, both the 2012 and 2015 elections were preceded by simmering conflicts that prompted the SADC to intervene. In 2012 the ruling LCD was split by a bitter internecine conflict just three months before the election. In 2015 Prime Minister Thabane's fragile coalition government collapsed during an even more intense struggle that compromised Lesotho's stability. Like prior splits in the ruling party prior to the 1998, 2002, and 2007 elections, the precipitating factors in 2012 and 2015 were not ideological or policy driven. Access to power, succession to party leadership, and personal rivalries have predominated - in a context where government employment is the primary source of wealth and opportunity.

Despite the precarious character of Lesotho's coalition governments after the 2012 and 2015 elections, these transfers of power reversed a malign precedent.

1 The National Assembly is the popularly elected lower house of Parliament. Entries on each political party, the electoral system, and elections as well as biographies of major political figures appear in Rosenberg \& Weisfelder (2013). 
Lesotho had failed its first test disastrously in 1970 when Leabua Jonathan's Basotho National Party (BNP) lost the election decisively to Ntsu Mokhehle's Basutoland Congress Party (BCP), but retained power with the help of the Lesotho security forces and the South African apartheid regime. The result was sixteen years of authoritarian civilian rule under Jonathan. This period was followed by seven years of military government after a successful coup in 1986.

Defeated parties strongly challenged the results of the 1993, 1998, and 2007 elections after Lesotho returned to constitutional civilian rule. Such challenges echoed the disruptive electoral disputes in 1965 and 1970 under Lesotho's original democratic constitution. The turmoil after the 1993 election was contained only after King Letsie III's abortive coup was reversed through coercive diplomatic intervention by Botswana, South Africa, and Zimbabwe. Similarly, opposition protests after the 1998 election created anarchy. This led Botswana and South Africa to intervene militarily under SADC auspices to restore Mosisili's elected LCD government, and to demand the reform of Lesotho's dysfunctional firstpast-the-post electoral system.

By contrast, after the successful 2002 election - which was conducted under the new mixed member system, even the disgruntled BNP joined nine other parties in the National Assembly. However, the 2007 election generated renewed turmoil because of a dispute about the allocation of the compensatory proportional seats in the National Assembly. This conflict persisted up until the 2012 election, with controversial reforms to the electoral system being enacted only in late 2011.

Despite the intercession of international, regional, and local mediators in both the 2012 and 2015 elections, prospects for legitimate outcomes seemed dim. However, these two elections altered the old paradigm of virulent partisan struggle in the aftermath of an election in Lesotho. Previously, the dominant party - with its substantial parliamentary majority - would be left wrangling with an aggrieved but marginal opposition. What has emerged instead is a pattern of intense partisan struggles within a weak multiparty coalition government, under constant duress from a substantial coalition of parliamentary opponents.

\section{OBJECTIVES}

This essay will merely note in passing the events and extensive literature regarding Lesotho's 1993 and 1998 elections, conducted under the first-past-the-post system, and their tragic aftermaths (Weisfelder 1999 \& 2001). It will not replicate sound published analyses of the 2002, 2007 and 2012 elections. Instead it will focus on the characteristics, outcomes, revisions and gaming of Lesotho's mixed member electoral system between 2002 and 2015. It will treat partisan manipulation of that system in 2007 as a crucial turning point. That episode signalled Lesotho's 
transformation from a single party dominant system into a multi-party pattern, typical of electoral systems with proportional representation and resultant coalition governments.

A key element in Lesotho's post-electoral conflicts has been the roles played by South Africa, SADC and other external actors. This intervention has been possible because of Lesotho's impacted geopolitical position and resultant economic and political vulnerabilities. The impact of those external players was accentuated in 2014 as they tried to prevent the collapse of Lesotho's first coalition government. Their activities expanded when that domestic conflict morphed into a quasi-military coup that included confrontations between elements of the Lesotho Defence Force (LDF) and the Lesotho Mounted Police Service (LMPS), aligned with rival parties.

Both the SADC presence and the politicisation of Lesotho's security services demand careful evaluation. The processes of coalition formation in 2012 and 2015, the nature of the component political parties and leadership, and the consequences of government by coalition all require attention. This essay evaluates Lesotho's recent experiences in the light of Staffan Lindberg's (2006) and Andrew Reynold's (1999) analyses of the relationships between elections and democratisation. Afrobarometer data for Lesotho are used to update Wonbin Cho and Michael Bratton's (2005) analysis of the impact of electoral reforms on 'citizen support for the country's state and regime.' (p. vii). Whether proposed electoral, constitutional and parliamentary remedies could be enacted and effect change will also be considered.

\section{CREATION OF THE MIXED MEMBER ELECTORAL SYSTEM AND ELECTION OF 2002}

Following their military intervention in 1998 to prevent the ouster of Mosisili's elected government, Botswana and South Africa, backed by SADC, insisted that his LCD accept the formation of an Interim Political Authority (IPA). The IPA was intended to restructure the dysfunctional electoral system. The presumed cause of the 1998 insurrection and of Letsie III's aborted coup in 1994 was that free and fair elections, under the first-past the-post constituency-based electoral system, had denied parliamentary representation to lesser parties. Yet these smaller parties had collectively gained as much as $40 \%$ of the vote. Hence their supporters had created anarchy through extra-parliamentary demonstrations, to press their claims that electoral chicanery had denied them their rightful place in Parliament. The IPA was intended to create and implement an alternative electoral system that would be more inclusive, have wider popular acceptance, and be perceived to be free and fair. It was also expected to create norms for appropriate behaviour among political parties (Rosenberg \& Weisfelder 2013, pp. 188-190, 266-268, 417-420). 
After protracted wrangling, the IPA agreed to a mixed system of first-pastthe-post plurality elections in 80 constituencies, with compensatory proportional representation for 50 additional seats (Likoti 2009, p. 58-62). The membership of the prior Independent Electoral Commission (IEC) was replaced. Claiming that its constitutional authority was being usurped, the LCD majority in Parliament reduced the number of proportional seats to 40 . The LCD reluctantly accepted the compensatory principle for the proportional component. As the dominant party, the LCD preferred a parallel system where constituency and proportional seats would be contested separately. This arrangement would permit the LCD to benefit from the proportional component, whatever its results in the constituencies.

The agreed upon system gave each voter two votes: one for a local constituency candidate and one for a political party. The compensatory proportional seats were allocated to parties, whose share of constituency seats was less than their proportion of the nationwide party vote. This scenario would ensure that the National Assembly would reflect the range of opinion nationally. Table 1 below shows the results of the 2002 election.

Table 1

2002 Election Results

\begin{tabular}{|c|c|c|c|c|c|}
\hline Parties & $\begin{array}{l}\text { Constituency } \\
\text { Seats }\end{array}$ & $\begin{array}{c}\% \\
\text { Party } \\
\text { Vote }\end{array}$ & $\begin{array}{c}\text { Compensatory } \\
\text { PR Seats }\end{array}$ & $\begin{array}{l}\text { National } \\
\text { Assembly } \\
\text { Seats }\end{array}$ & $\begin{array}{c}\% \\
\text { Assembly } \\
\text { Seats }\end{array}$ \\
\hline BAC & - & 2.9 & 3 & 3 & 2.5 \\
\hline BCP & - & 2.7 & 3 & 3 & 2.5 \\
\hline BNP & - & 22.4 & 21 & 21 & 17.5 \\
\hline LCD & 79 & 54.8 & - & 79 & 65.9 \\
\hline LPC & 1 & 5.8 & 4 & 5 & 4.2 \\
\hline LWP & - & 1.4 & 1 & 1 & .8 \\
\hline NIP & - & 5.5 & 5 & 5 & 4.2 \\
\hline NPP & - & .7 & 1 & 1 & .8 \\
\hline MFP & - & 1.2 & 1 & 1 & .8 \\
\hline PFD & - & 1.1 & 1 & 1 & .8 \\
\hline Others & - & 1.5 & - & - & 0.0 \\
\hline
\end{tabular}


As in the disputed 1998 election, the LCD was the dominant party, winning all but one of the constituency contests. This time, the LCD's opponents accepted the legitimacy of the 2002 outcome because the proportional component permitted nine opposition parties to participate within the system rather than demonstrate in the streets. Election observers viewed the process and outcome as free and fair (Southall 2003). Freedom House's annual assessment of Lesotho's performance regarding civil liberties and political rights immediately improved from a 'partly free' rating to the 'free' category.

Despite internal conflicts within his party, this electoral legitimacy provided Prime Minister Mosisili with popular support. His stable parliamentary majority meant he had little need to court the opposition parties. However, what had an unexpected impact in the 2007 election was that the unheralded National Independent Party (NIP) led by Anthony Manyeli had gained five National Assembly seats through proportional representation. Manyeli himself acknowledged that this was probably a case of mistaken identity. The LCD had told its supporters to 'vote the bird' in the party vote. Many of them had apparently mistaken the NIP dove for the LCD eagle!

\section{THE 2007 ELECTION AND MIXED MEMBER PROPORTIONAL ELECTORAL DISPUTE}

The conduct of the 2007 election generated little controversy and was deemed free and fair by domestic and international observers. Long-simmering grievances within the LCD, however, had been accentuated by several factors. These included Mosisili's failure to address festering corruption; growing politicisation of the civil service; and the grievances of urban workers, especially in the textile industry. These concerns were exacerbated by the rise of the mercurial Monyane Moleleki in the struggle to succeed Mosisili, should he retire.

On 13 October 2006, Motsoahae Thomas Thabane led a bloc of 18 members of the National Assembly to break with the LCD and form the All Basotho Convention $(\mathrm{ABC})$. What made the new party formidable was the likelihood of its cracking the phalanx of LCD constituency seats, the extensive political experience of its leader, and the security provided by proportional seats should its support in constituencies prove less than expected. With his parliamentary majority reduced to two, elections pending, and poor prospects for regaining the lost seats, Mosisili dissolved Parliament. He called a snap election before the new party could organise and campaign effectively. Incumbents gain from choosing when to seek a new mandate whenever Parliament has a maximum rather than fixed term of office.

Mosisili's next move threatened the legitimacy of the mixed member system and led to five years of post-election turmoil. Recalling the voter confusion of 
2002, the LCD forged an alliance with the NIP. The LCD ran only constituency candidates and instructed its supporters to 'vote the bird' - namely for the NIP dove - in the party vote. The resultant NIP list for proportional representation was an amalgam of LCD and NIP members who had pledged to support the LCD in Parliament. The NIP participants accepted the alliance as a survival strategy, understanding that the 2002 'accident' would not otherwise be repeated. This stratagem transformed the compensatory format of proportional representation into the parallel system which the LCD had preferred. The LCD had gained no compensatory proportional seats in 2002 because constituency victories gave them more seats than justified by their share of the national vote. The LCD hoped the alliance would fend off the $\mathrm{ABC}$ challenge by adding proportional seats without regard for constituency victories. To counter this ploy, the $\mathrm{ABC}$ formed a similar alliance with the Lesotho Worker's Party (LWP), fielding only constituency candidates itself, and telling its supporters to vote for the LWP party list. Table 2 below shows the results for the 2007 election.

Table 2

2007 Election Results

\begin{tabular}{|c|c|c|c|c|c|}
\hline Parties & $\begin{array}{c}\text { Constituency } \\
\text { Seats }\end{array}$ & $\begin{array}{c}\% \\
\text { Party } \\
\text { Vote }\end{array}$ & $\begin{array}{c}\text { Compensatory } \\
\text { PR Seats }\end{array}$ & $\begin{array}{c}\text { National } \\
\text { Assembly } \\
\text { Seats }\end{array}$ & $\begin{array}{c}\% \\
\text { Assembly } \\
\text { Seats }\end{array}$ \\
\hline $\mathrm{ABC}$ & 17 & - & - & 17 & 14.2 \\
\hline ACP & 1 & 4.6 & 1 & 2 & 1.7 \\
\hline BBDP & - & 1.9 & 1 & 1 & .8 \\
\hline $\mathrm{BCP}$ & - & 2.2 & 1 & 1 & .8 \\
\hline BDNP & - & 2.0 & 1 & 1 & .8 \\
\hline BNP & - & 6.8 & 3 & 3 & 2.5 \\
\hline LCD & 62 & - & - & - & 51.7 \\
\hline LWP & - & 24.3 & 10 & 10 & 8.3 \\
\hline MFP & - & 2.1 & 1 & 1 & .8 \\
\hline NIP & - & 51.8 & 21 & 21 & 17.5 \\
\hline NLFP & - & .9 & - & - & - \\
\hline PFD & - & 3.5 & 1 & 1 & .8 \\
\hline $\begin{array}{l}\mathrm{LCD} / \\
\mathrm{NIP}\end{array}$ & 62 & 51.8 & 21 & 83 & 60.8 \\
\hline $\begin{array}{l}\mathrm{ABC} / \\
\mathrm{LWP}\end{array}$ & 17 & 24.3 & 10 & 27 & 22.5 \\
\hline
\end{tabular}


The strategy worked. It gave the LCD alliance a large parliamentary majority with 62 constituency seats and 21 additional seats through proportional representation. Seven smaller parties were the big losers. They won ten proportional seats, but would likely have gained 28 if the IEC had treated the alliances as two unified parties rather than four separate ones. The opposition parties took their seats in the National Assembly, but vehemently disagreed with the IEC interpretation of the law and allocation of proportional seats. Independent observers expressed concern that the IEC decision had violated the spirit and intent of the mixed member format and threatened the ongoing democratisation of Lesotho (Elklit 2008; Makoa 2008; Matlosa 2008). The Freedom House rating for Lesotho fell back to 'partly free.' By contrast, the American ambassador saw no problem when techniques that were not legally prohibited were used to gain an electoral advantage (Fulbright-Hays group briefing, July 2008).

A parliamentary 'sit-in' by five opposition parties protesting the allocation of proportional seats led to their forcible ejection by the Lesotho Defence Force (LDF). When dissent spilled into the streets, Maseru was paralysed by a general strike, with most opposition groups joining in. The strength of the ABC/LWP alliance within Maseru and other urban areas posed a huge challenge for the rurally based LCD government. Alarmed by this new bout of instability in Lesotho, the executive secretary of SADC launched what would become a multiyear initiative to examine the causes of the conflict and promote its resolution. With that assurance, opposition leaders suspended their strike, perhaps wary of replicating the 1998 post-election debacle.

A troika of ministers from SADC states arrived in Lesotho to evaluate the sources of the problem. Prime Minister Mosisili denied that there was anything to discuss with the opposition. However, after the troika had met with government and opposition leaders, it identified the main causes of the dispute as being party alliances, manipulation of the electoral system, and flawed communication among political leaders. The troika's report led to a SADC-sponsored 'dialogue' about the allocation of the compensatory proportional seats. Ketumile Masire, a former president of Botswana, was the designated mediator.

When these talks yielded no progress, a rash of inchoate violence ensued, targeting LCD cabinet ministers and even ABC leader Thabane. With curfews in effect, security forces treated opposition supporters roughly, with threats, arrests, and alleged incidents of torture. Although the disturbances produced only temporary disruptions, the dispute became a source of renewed factionalism and indiscipline in the LDF. The result was charges of sedition and other offenses against perpetrators. One of the officers who fled to South Africa was later involved in a bizarre plot to assassinate Mosisili. He recruited the Mozambican mercenaries who penetrated an LDF base in April 2009 and used captured arms 
and vehicles to attack State House, the prime minister's residence. The mercenaries were eventually repulsed by LDF guards. The challenges to the legitimacy of the LCD parliamentary contingent undoubtedly facilitated these disquieting events.

Masire's mediation was derailed by an electoral challenge bought before Lesotho's High Court. When the Court ignored the clear intent of the mixed member system and affirmed the IEC allocation of the proportional seats on largely technical grounds, momentum toward a negotiated settlement ceased. Masire eventually halted his efforts when the ruling LCD declined to proceed further, stating that the dialogue had 'run its course.' Mosisili condemned Masire's final report to SADC as having done nothing to bring resolution but merely adding fuel to the fire. Masire (2009) had criticised the way electoral alliances had been created and the mixed member electoral model had been applied. He called for legislative action to remedy those problems, to permit courts to hear election petitions, to create criteria for selection of the leader of the parliamentary opposition, and to foster prevalence of national interests over partisan interests (Bane 2009).

Following the failure of Masire's mission and of subsequent SADC delegations to produce rapprochement, leadership passed to the Christian Council of Lesotho, working together with civil society organisations, foreign donors, and the UN Development Programme's Democratic Governance project. Initial agreements foundered when the protagonists seemed more committed to keeping their old vendettas alive than reaching a settlement. Infighting persisted within the opposition ranks. Nevertheless, the chairman of the Christian Council, Bishop Phillip Mokoku, kept the discussions going until April 2011, when he announced that agreement about needed reforms had been reached.

\section{THE 2011 ELECTORAL REFORMS AND 2012 ELECTION}

The Electoral Reform Act of 2011 ended the 2007 electoral dispute with changes that were acceptable to the major parties. Voters would simultaneously choose a local constituency candidate and that candidate's party for compensatory proportional representation, through a single ballot. Voters could no longer vote for a party other than that of their favoured constituency candidate; nor could they vote for their preferred party if it lacked a local constituency candidate. Electoral pacts were precluded unless registered with the IEC and treated as a single party slate for both constituency and proportional purposes. Parties could question the allocation of proportional seats in court. All parties were required to submit 'zebra' lists in which men and women's names were alternated for proportional representation, thereby guaranteeing greater gender equality in Parliament. New reporting requirements to the IEC were required of registered parties as well as a set of standardised provisions to be included in party constitutions. Contributions 
of more than M200 000 (\$20 000) to any party had to be reported. External election observers were guaranteed free access to all electoral participants and to local and international media.

Both external and domestic electoral observers considered the 2012 general election to be free and fair, and congratulated the IEC on a well managed process (Commonwealth Observer Group 2012). No party rejected the overall outcome. The 2013 Freedom House ranking moved Lesotho back to its 'free' category. The prelude to the election, however, had shown up the highly contentious interactions between parties and the internecine conflicts within them.

Had it remained unified, the LCD would have had a huge victory. But in February 2012, years of recrimination between Monyane Moleleki's 'Fire-eater' faction and Mothetjoa Metsing's 'Fire-extinguishers' finally tore the LCD apart. Mosisili, like Mokhehle in 1997, responded to the loss of control over his party executive by forming a new party, the Democratic Congress (DC). He continued to govern through controversial parliamentary manoeuvres (Letsie 2013, p. 7172). After passing last-minute legislation to facilitate the election, Parliament was dissolved, leaving the prior Cabinet intact, including rival LDC and DC ministers. Struggles between the factions to control the fractured LCD party apparatus and financial resources remained unresolved until those issues were rendered moot by the election results.

Post-election commentaries have typically ignored the internecine strife within the other parties - although this boded ill for an effective coalition government. Tom Thabane's leadership had been criticised as authoritarian, and was blamed for defections of party members and the loss of two parliamentarians from the ABC fold. The ABC/LWP alliance had ended bitterly in 2010 when Macaefa Billy, the LWP leader, was ousted as ABC secretary general. Failure to compete effectively with the LCD in several parliamentary by-elections added to the rancour. Billy may have been prescient when he denounced Thabane as an authoritarian who would head a 'rotten administration' should he become prime minister (Lesotho Times 2011). Conflict within the BNP over Metsing Lekhanya's leadership dated back to 2001, and had resulted in a split in 2006. ${ }^{2}$ That conflict had intensified following the collapse of BNP electoral support in 2007, culminating in Lekhanya's hotly contested ouster in 2010. Thesele 'Maseribane eventually prevailed to lead the BNP, an outcome confirmed only after lengthy legal battles. Several smaller parties also suffered damaging internal conflicts. Table 3 below shows the results of the 2012 election.

2 Metsing Lekhanya was the general who led the coup that overthrew Leabua Jonathan in 1986 and headed the Military Council thereafter. Ironically, in 1999 he became leader of the BNP, the party he had ousted. 
Table 3

2012 Election results

\begin{tabular}{|c|c|c|c|c|c|}
\hline Parties & $\begin{array}{c}\text { Constituency } \\
\text { Seats }\end{array}$ & $\begin{array}{c}\% \\
\text { Party } \\
\text { Vote }\end{array}$ & $\begin{array}{c}\text { Compensatory } \\
\text { PR Seats }\end{array}$ & $\begin{array}{c}\text { National } \\
\text { Assembly } \\
\text { Seats }\end{array}$ & $\begin{array}{c}\% \\
\text { Assembly } \\
\text { Seats }\end{array}$ \\
\hline $\mathrm{ABC}$ & 26 & 25.18 & 4 & 30 & 25.0 \\
\hline BBDP & - & .44 & 1 & 1 & .8 \\
\hline $\mathrm{BCP}$ & - & .46 & 1 & 1 & .8 \\
\hline BDNP & - & .62 & 1 & 1 & .8 \\
\hline $\mathrm{BNP}$ & - & 4.31 & 5 & 5 & 4.2 \\
\hline DC & 41 & 39.58 & 7 & 48 & 40.0 \\
\hline LCD & 12 & 21.94 & 14 & 26 & 21.7 \\
\hline LPC & - & .91 & 1 & 1 & .8 \\
\hline LWP & - & .44 & 1 & 1 & .8 \\
\hline MFP & - & .60 & 1 & 1 & .8 \\
\hline NIP & - & 1.24 & 2 & 2 & 1.7 \\
\hline $\mathrm{PFD} / \mathrm{K}$ & 1 & 2.02 & 2 & 3 & 2.5 \\
\hline Others $^{1}$ & - & 2.20 & - & - & - \\
\hline Coalition $^{2}$ & 38 & 51.43 & 23 & 61 & 50.83 \\
\hline Opposition $^{3}$ & 41 & 40.02 & 8 & 49 & 40.83 \\
\hline The Block ${ }^{4}$ & 1 & 6.29 & 9 & 10 & 8.34 \\
\hline
\end{tabular}

${ }^{1}$ Included four small parties and nine independents with PR lists

2 Included ABC, BNP, and LCD

${ }^{3}$ Included DC and BBDP

${ }^{4}$ Initially supporting the coalition: BDNP, BCP, LPC, LWP, MFP, NIP, and PFD

Source: Compiled by the author from Independent Electoral Commission data (2012)

The 2012 election outcome was not a straightforward popular repudiation of Mosisili and his government (Ambrose 2012a, pp. 11-22; Letsie 2013, pp. 6770, 72-75). A plurality of Basotho voters preferred that Mosisili continue to lead the country. Thabane's claim to coalition leadership rested on only $25.2 \%$ of the vote for the ABC. His party had gained a majority only in his own constituency, 
compared with majorities for the DC in 20 constituencies and for the LCD in three. Fifteen of the $26 \mathrm{ABC}$ constituencies were carried by pluralities of less than $40 \%$ of the vote, and in 22 constituencies the combined vote for the DC and LCD was greater than the $\mathrm{ABC}$ total. The $26 \mathrm{LCD}$ seats versus $\mathrm{ABC}$ 's 30 gave Metsing almost as strong a claim to coalition leadership and the expectation of being treated as an equal partner. With only five proportional seats, no constituency victories, and only $4.3 \%$ of the party vote, 'Maseribane's BNP seemed destined to play a lesser role.

The composition of the new National Assembly closely tracked the percentages gained in the party vote, lessening the prior disparities which had favoured any party that won a large block of constituency seats. The entrenched political class still dominated ministerial positions, and Prime Minister Thabane - the oldest constituency representative - had served in every government since independence. Almost unnoticed, the greatest change was the election of 75 new members to the National Assembly, compared with the retention of only 45 incumbents: an unprecedented infusion of new blood (Ambrose 2012b, p. 4). Half of the winning candidates in constituencies were younger than 50 years, while only 15 candidates were older than 60 . Women garnered 31 seats in the National Assembly, five among the 23 Cabinet posts, and three of seven appointments as assistant ministers.

The voter turnout was a mere $50.4 \%$ of registered voters. This scenario was aggravated by the continued failure to provide absentee voting for Basotho residing in or visiting South Africa (Weisfelder 2014). Eighteen parties entered constituency candidates and party lists, with four of them contesting almost every seat. An additional eight parties competed in at least 50 of the 80 constituencies. To qualify for proportional representation, parties had to field constituency candidates. That requirement encouraged more than 1000 constituency candidates to stand for election, including 55 independents.

The 2012 general election perpetuated the preponderance of fragments from the LCD, which collectively gained almost $88 \%$ of party votes. Party manifestos reflected a paucity of ideological and policy differences among the competitors, and confirmed that the key sources of division were personal conflicts, factional rivalries, and struggles to control governmental posts and assets. The election results also revealed a huge urban/rural divide, with the DC dominating the rural southern and mountain districts, the LCD dominating the more rural segments of the northern districts, and the $\mathrm{ABC}$ dominating most of the urban areas. Urban voters may have been more aware of government deficiencies, whereas rural voters possibly gave greater support for government poverty alleviation programmes, including old age pensions and free primary education (Letsie 2013, p. 80). 


\section{FORMATION, FUNCTIONING, AND FAILURE OF LESOTHO'S FIRST COALITION GOVERNMENT}

The 2012 election produced an unprecedented coalition government that held a bare majority of 61 seats, but its composition presaged the strains that led to its demise. Thabane, as leader of the coalition's largest parliamentary contingent $(\mathrm{ABC})$, became prime minister. However, his dependence on LCD support was evident in Metsing's appointment as deputy prime minister and in the distribution of Cabinet posts. The $L C D$ received ten ministries versus eleven for the $A B C$, but the LCD ministers had far more extensive Cabinet experience than their ABC colleagues. Moreover, retired LCD parliamentarian Sephiri Motanyane became the influential Speaker of the National Assembly. Although the five BNP parliamentary seats were essential to the coalition majority, the BNP gained only two Cabinet posts, which were not highly prestigious.

Support from the 'Bloc' - a group of nine parliamentarians from six small parties that were not part of the coalition but were eager for emoluments - gave Thabane's government a working majority. With three seats in the Bloc, PFD leader Lekhetho Rakuoane was appointed Deputy Speaker. Vincent Malebo, the Bloc's spokesperson, was rewarded by being appointed to the Council of State that advises the King, and became chair of the influential parliamentary Public Accounts Committee.

Mosisili alleged that discussions of an LCD/DC coalition had failed when Metsing insisted on becoming prime minister despite the DC's larger parliamentary delegation. Mosisili claimed that he and Monyane Moleleki would have stepped aside in favour of a less controversial DC candidate, with Metsing as deputy prime minister. But the LCD stood to gain fewer ministries in coalition with the DC than with the ABC. Moreover, the wounds from the recent split between the LCD and DC were too raw for any immediate rapprochement. Reconciled to opposition status, Mosisili alleged that his former LCD compatriots had 'sold out' to the ABC and BNP 'nationalists' instead of joining with their natural DC allies who had won more seats and votes (Ntaote 2012). Thereafter he played on rifts among the coalition members, much as Ntsu Mokhehle's obdurate opposition had done after Leabua Jonathan's 1965 electoral victory. Collapse of the coalition would lead to a new coalition that could include the DC, or to an early election held under inauspicious circumstances for the quarrelling incumbents.

Internal friction was immediately evident within the coalition itself. Though eager to assert its newfound importance, 'Maseribane's BNP bonded with Thabane against the far deeper rift between Thabane and Metsing. To transcend disagreements that threatened its survival, the coalition participated in workshops organised by the United Nations Development Programme governance section. 
The coalition also sought advice from Commonwealth consultants and other experts on conciliation and negotiation, as well as local groups like the Christian Council. The coalition partners had never melded their priorities into a substantive working agenda (Zihlangu 2013). Their differences centered on Thabane's alleged failure to consult the LCD on his appointments to the Cabinet, senior civil service and judiciary.

Foreign Minister Mohlabi Tsekoa of the LCD claimed that the 'foundations of the coalition government' were being undermined by Prime Minister Thabane applying political criteria to the appointment of diplomats instead of depoliticising the process (Lesotho Times 24 October 2013). Prosecutions that stemmed from Thabane's longstanding crusade against corruption were questioned as politically motivated. Top civil servants and ministers from the former government were targeted, as were certain people serving within the coalition, including LCD minister Tim Thahane. To his credit, Thabane encouraged the Directorate on Corruption and Economic Offences to pursue corruption wherever it was found, and immediately fired an $\mathrm{ABC}$ minister who had assaulted a civil servant. However, the lack of shared priorities within the coalition was evident in September 2013 when the President of the Senate deplored the minimal amount of legislation emerging from the National Assembly (Ambrose 2013, p. 22).

Another portent of the cycle of recrimination within the coalition and the conflagration ahead occurred when the LCD publicly denounced Thabane's attempt to move the critical Highlands Water Project from an LCD-held ministry to his own office (Sunday Express 14 September 2013). Partisan conflict between the army (LDF) and police (LMPS) emerged when Thabane appointed Khothatso Tšooana, a 35-year-old from his constituency, as Police Commissioner. Later forensic investigation blamed the Special Forces Unit of the LDF for explosions at Tŝooana's house and nearby at the home of Thabane's long-term mistress (Ambrose 2014a, pp. 1, 3-4). LDF Commander Tlali Kamoli's refusal to permit questioning of the suspects fuelled the dispute with the police. When a Cabinet committee failed to resolve the conflict, the SADC Organ on Politics, Defence and Security Cooperation was asked to intervene. But the deadlock persisted even though the chairperson, Namibian President Hifikepunye Pohamba, flew to Maseru to mediate the dispute between the security forces and to try and resolve the escalating crisis among the coalition partners.

Meanwhile, the dismissal of Thahane and changes in the composition of the $\mathrm{ABC}$ national executive prompted Thabane to reshuffle his Cabinet twice. Two dismissed ministers bolted from the $\mathrm{ABC}$, took shelter in South Africa after alleged death threats, and joined with the DC and the small but increasingly disgruntled parties in the Bloc. This 'grand coalition' sought an immediate a vote of no-confidence in Thabane's government. Procedural issues deflected the vote 
when, on 26 March, Metsing - still operating within the coalition - managed to guide the passage of a motion to adjourn Parliament indefinitely. Soon thereafter, Thabane terminated several senior civil servants, some of whom faced corruption charges, and appointed new principal secretaries to head the bureaucracy in several ministries. Metsing's public criticism of Thabane's removal of DC-oriented personnel fuelled rumours that he had agreed to form a new coalition government with Mosisili's party (Koloi 2014b). Parliament reopened briefly and recessed after another unproductive session.

To prevent the collapse of his administration, Thabane advised King Letsie III to prorogue Parliament from 10 June through 27 February 2015. Some observers argued that prorogation would provide a cooling-off period for the coalition partners to 'iron out their differences' (Zihlangu 2014). In reality, it intensified the conflict by removing any moderating element of parliamentary deliberation, triggering sustained intervention by SADC and South Africa, and accentuating the struggle among the politicized security forces (Ambrose 2014b, pp. 18-27 \& 2014c, pp.1-6, 18-19, 22-23). Immediately thereafter, Metsing condemned Thabane for having acted without the consent of his LCD coalition partners. Metsing announced his plans to join with the DC and small parties to form an alternative coalition government-but how that could occur with Parliament closed remained unclear. Moreover, several key LCD ministers were absent at Metsing's press conference, suggesting their continued loyalty to Thabane's coalition and an impending split within LCD ranks (Zihlangu \& Ntaote 2014).

As the stalemate persisted, the Commonwealth Secretariat arranged for a long-postponed study tour to New Zealand finally to take place. The delegation included 25 parliamentarians, including Metsing. Their objective was to examine the functioning of New Zealand's mixed member electoral system and processes for forming coalitions. At a press conference on 25 July 2014, the contending coalition leaders all agreed that the 50-page report prepared by Commonwealth expert Rajen Prasad would provide the basis for improved working relationships and governance (Ambrose 2014c, p. 1-3). However, the planned discussion of that report foundered at peace talks among the coalition parties when the LCD insisted on revocation of the prorogation of Parliament, and both the $\mathrm{ABC}$ and BNP demanded an end to the new LCD coalition agreement with the DC (Ntaote 2014a).

On 29 July 2014, South African President Jacob Zuma arrived in Lesotho to consult King Letsie III and to help the protagonists 'address the challenges as seriously and as amicably as possible' (Chimombe 2014). Zuma persuaded the leaders to visit Namibia immediately for further mediation. As a result, Metsing agreed to renounce his coalition with the DC, which he did publicly; and Thabane consented to recall Parliament within fourteen days, a promise he did not fulfil. 
Upon their return to Lesotho, Metsing was served at the airport with a summons to answer pending charges of corruption. Although the indictment was temporarily withdrawn after being read in court, the public venue and timing of the summons and proceeding seemed designed to humiliate him, and exacerbated the crisis (Tefo 2014).

Thabane continued to make controversial decisions that raised LCD hackles. He granted diplomatic passports to Zuma's allies, the controversial Gupta family; and attempted to force out the incumbent Attorney General and Director of Public Prosecutions. Thabane's most daring action was to dismiss LDF Commander Tlali Kamoli on 29 August and, rubbing salt in the wound, replacing him with Maaparankoe Mahao. Mahao had gained regional recognition for competently heading the SADC Planning Unit in Botswana for the Joint Standby Force. Upon his return to Lesotho, Mahao had been suspended, pending the outcome of a court martial, for rebuking a subordinate who had questioned the right of civilian authorities to replace the LDF commander.

On 30 August 2014, Thabane, Mahao and numerous ABC and BNP leaders fled to South Africa after a quasi-coup led by Kamoli, in which the LDF attacked the LMPS headquarters. They wrecked the premises, seized many vehicles and weapons, and caused one death and serious injuries to other people. They confiscated arms alleged to be destined for ABC supporters, and dockets about soldiers who were suspected of carrying out the earlier bombings. They also seized the prime minister's residence and attacked Mahao's home. However, they did not take control of the government.

As the new chair of the SADC Organ on Politics, Defence and Security Cooperation, Zuma summoned the coalition leaders to Pretoria. There they gave their commitment to a joint declaration to lift the prorogation of Parliament and to work to restore law and order. Thabane returned to Lesotho guarded by a substantial contingent of South African police, which - together with other SADC security contingents - would protect him and BNP leader 'Maseribane until after the 2015 election. Prorogation was lifted, but Thabane declined to reopen Parliament until security was restored, because Kamoli refused to relinquish command of the LDF.

On 15 September 2014, 72 members of Parliament issued a joint statement that identified Thabane as 'the sole source of Lesotho's problems' (Ntaote 2014b). The statement also supported Kamoli's retention as LDF commander, and condemned the presence of foreign forces protecting the prime minister as a violation of Lesotho's sovereignty (Ntaote 2014b). On that same day, an Extraordinary SADC Summit produced regional consensus that South African Vice President Cyril Ramaphosa would serve as the facilitator to assure the reopening of Parliament and the holding of early elections in Lesotho. He would be supported by a SADC 
politics, defence and security observation mission. This observation mission ultimately included personnel from Angola, Botswana, Malawi, Namibia and South Africa.

Under strong pressure from Ramaphosa, Lesotho's major parties assented to the Maseru Facilitation Declaration on 2 October 2014. The declaration provided for an immediate session of Parliament to be held to deal with urgent business, followed by its dissolution and an election in late February 2015. Parliament reopened on 17 October with unprecedented security provided by South Africa police, armoured vehicles, scanners and sniffer dogs (Ntaote 2014c). In his opening speech, King Letsie III, free to express his own concerns, denounced the failed political leadership, deplored the resultant politicisation of the security agencies, and noted the need for Lesotho to 'put its own house in order instead of expecting others to do it for us'(Ambrose 2014c, p. 3-4) Before its dissolution on 5 December, Parliament failed to resolve the budgetary matters and electoral questions for which it had been convened, concluding its dismal performance under the leadership of Thabane's coalition.

Endemic insecurity persisted, with further confrontations taking place between LDF special forces and LMPS special operation units. To resolve this impasse, Ramaphosa persuaded the major parties to accept the Maseru Security Accord, which sent Kamoli, Mahao and Tŝooana on leave of absence to SADC and other African states. These three men pledged to do whatever they could to ensure that their subordinates would not engage in further hostilities, and to cooperate with the SADC Facilitation Mission in Lesotho in maintaining law and order (Ntaote 2014d).

Although there was one serious incident in early February and other lesser ones, the deployment of 475 police from the DRC, Malawi, Namibia, South Africa and Swaziland during the week prior to the election guaranteed security. The LDF remained in its barracks while SADC police and election observers monitored every aspect of the electoral process (Ambrose 2015a, p. 17). Unfortunately, rogue behaviour within the LDF was merely suspended rather than being investigated or resolved, and re-emerged after the election.

Except for the initial weeks of September 2014, life in Maseru and the countryside remained surprisingly normal during the slow disintegration of the coalition government, the long period of security force confrontations, and the subsequent election campaign. One convincing explanation is that most citizens were spectators at what they perceived to be a game largely confined to the political class and security services. While observers closely linked to the political scene feared a descent into total chaos, ABC supporters doffed their gold apparel, and DC partisans their red, to cheer on their favourite 'teams' in the contest between the two strongest parties. 


\section{THE 2015 ELECTION AND SECOND COALITION GOVERNMENT}

Foreign and domestic observer missions found the conduct of the election on 28 February 2015 to be free and fair. Despite the partisan cast of members of the Independent Election Commission (IEC) and misgivings in the commission's own ranks about its ability to manage a credible election at such short notice (Lesotho Times 15 January 2015), the IEC delivered a remarkably clean poll (Koloi 2014a). The report of the SADC mission (Interim Mission Statement 2015) listed fifteen positive findings, but was critical of unbalanced media coverage, poor representation of women among the constituency candidates, and the absence of a code of electoral conduct for the security services and media. Its foremost criticism was the need for institutional, political and legal reforms to improve governance and the formation and functioning of ruling coalitions in the aftermath of elections. The large disparities in numbers of registered voters per constituency and the national turnout of less than $50 \%$ of eligible voters should also spur concern.

Because this was a 'snap' election held two years ahead of schedule, the electoral system and constituency boundaries remained unchanged from 2012. This facilitates comparative analysis. In 2015, a record 23 political parties entered candidates in some or all of the 80 constituency contests, a necessary step to be eligible for compensatory proportional representation under the single ballot system. Most parties, however, lacked manifestos. The few which made their manifestos available showed minimal ideological or policy differences, with the main variation between the parties being the degree of emphasis they placed on particular government programmes (Election Special 2015). More than 1100 candidates competed, $30 \%$ of who were women, with only ten female winners. The chance of gaining a well-paid parliamentary sinecure through proportional representation seems to have motivated leaders of the many tiny parties. Twenty women were elected through the zebra ballot lists required for proportional representation, so that 30 women presently constitute $25 \%$ of the new National Assembly. Table 4 below shows the results of the 2015 election.

Thabane's ABC dominated the urban and northern lowland constituencies. It gained seven seats in the Leribe District from Metsing's LCD. It won the two DC-held constituencies in remote Mokhotlong, which were likely to be affected by construction of the Polihali Dam, a project initiated by the former Mosisili administration. Elsewhere, the $\mathrm{ABC}$ gained two additional seats from $\mathrm{LCD}$, one from PFD, and four more from DC, but lost two to DC. Compared with 2012, the $A B C$ 's net gain was fourteen seats.

The DC retained most of its rural, mountainous, southern base, gaining one seat from $\mathrm{LCD}$, losing one to BNP and suffering a net loss of four to ABC. Compared with 2012, the DC's seats dropped by four from 41 to 37. 
Table 4: 2015 Election Results

\begin{tabular}{|c|c|c|c|c|c|}
\hline Parties & $\begin{array}{c}\text { Constituency } \\
\text { Seats }\end{array}$ & $\begin{array}{c}\% \\
\text { Party } \\
\text { Vote }\end{array}$ & $\begin{array}{c}\text { Compensatory } \\
\text { PR } \\
\text { Seats }\end{array}$ & $\begin{array}{l}\text { National } \\
\text { Assembly } \\
\text { Seats }\end{array}$ & $\begin{array}{c}\% \text { National } \\
\text { Assembly } \\
\text { Seats }\end{array}$ \\
\hline $\mathrm{ABC}$ & 40 & 38.13 & 6 & 46 & 38.33 \\
\hline BCP & - & .48 & 1 & 1 & .83 \\
\hline BNP & 1 & 5.59 & 6 & 7 & 5.84 \\
\hline $\mathrm{DC}$ & 37 & 38.76 & 10 & 47 & 39.17 \\
\hline LCD & 2 & 10.01 & 10 & 12 & 10.0 \\
\hline LPC & - & .35 & 1 & 1 & .83 \\
\hline MFP & - & .61 & 1 & 1 & .83 \\
\hline NIP & - & .96 & 1 & 1 & .83 \\
\hline PFD & - & 1.74 & 2 & 2 & 1.67 \\
\hline RCL & - & 1.19 & 2 & 2 & 1.67 \\
\hline Others $^{1}$ & - & 2.18 & - & - & 0 \\
\hline Coalition $^{2}$ & 39 & 52.91 & 26 & 65 & 54.17 \\
\hline Opposition $^{3}$ & 41 & 44.91 & 14 & 55 & 45.83 \\
\hline
\end{tabular}

${ }^{1}$ Includes 13 small parties and about 5500 votes for independents not included in the party vote percentages

2 Includes BCP, DC, LCD, LPC, MFP, NIP and PFD

${ }^{3}$ Includes ABC, BNP and RCL

Compiled by the author from Independent Electoral Commission data (2015)

The largest loser was Metsing's LCD. Party members who opposed his break with the Thabane coalition had created the Reformed Congress of Lesotho (RCL), which took away LCD votes and captured two proportional seats. The LCD was annihilated in its former Leribe base and fell from twelve to two constituency seats. Had Metsing entered a pre-election coalition with Mosisili, their combined votes could have reduced the $\mathrm{ABC}$ victory by seven seats and would easily have held the seat won by the BNP. Standing for the first time as incumbents augmented the ABC and BNP's credibility, and swelled their bases of support.

With a slight edge in the total vote, the DC gained 47 parliamentary seats compared with 46 for $\mathrm{ABC}$, twelve for $\mathrm{LCD}$, seven for $\mathrm{BNP}$, and eight seats divided among six minor parties.

When the results were announced, Mosisili declared that he had assembled a coalition that would command a majority. It included his DC (47 seats) and Metsing's LCD (12), plus PFD (2), NIP (1), BCP (1), LPC (1) and MFP (1) - a total 
of 65 seats. On 17 March 2015, Mosisili was sworn in at a colourful ceremony in Setsoto Stadium with the ABC yellow and DC red predominating. For the second time in three years, power was peacefully transferred to the former opposition, this time by Thabane. Thabane, Mosisili and Zuma all praised Ramaphosa for his resolution of the intractable obstacles to the creation of the newly elected coalition government.

The process of allocating positions in the new Cabinet, however, was not completed until 27 March. This led pundits to name the coalition 'the coat of many colours' or '7de Laan' - the latter after a popular South African soap opera (Ambrose 2015a, p. 31). On 30 March, the 27 new ministers and seven deputy ministers, including eight women, were sworn in. With its objectives realised, Ramaphosa officially closed the SADC mission in Lesotho on the same day.

The new Cabinet had five more ministries than its 2012 predecessor, and awarded each of the minor parties a full ministry. Despite having caused a split in his party, losing over half his 2012 parliamentary contingent, and being primarily responsible for destroying the 2012 coalition, Metsing was again appointed as deputy-prime minister. His party gained five ministries (counting three appointed Senators) and one deputy minister. The DC was clearly dominant, gaining 16 ministries and 5 deputy ministers, but still depended on the smaller parties to sustain the coalition majority. The ABC, BNP and RCL - with a total of 55 seats - constituted the opposition bloc.

Mosisili claimed that he had learned from Thabane's 'many blunders' how to keep his coalition functioning for its five-year term (Mohloboli 2015a). Neither he nor Metsing would be 'burdened' with leadership of specific ministries like Thabane and Metsing had been, but would 'monitor' the performance and effectiveness of all ministries (Mohlobili 2015a). Some commentators questioned whether Mosisili would bring in enough 'new blood' for a fresh start and resist the clamour from DC colleagues who were eager 'to return to their cabinet posts and the prestige, and sense of power'; or whether he would merely recycle the 'deadwood' from his prior cabinets (Mohloboli 2015a). On the campaign trail, Mosisili had conceded that he needed to be more sensitive to popular interests than he had been in the past, rather than just being informed by his inner circle (Zihlangu 2015a).

How well did Mosisili succeed in bringing in new blood? Only seven of his 27 full ministers appear to have served in recent Cabinets. The five ministers from minor parties have all had prior parliamentary experience, as have ten other ministers. Five are wholly new to either the National Assembly or Senate. Of the five appointed senators in the Cabinet, two appointed to Finance and Defence are old ministerial hands, whereas four others seem to bring special expertise from administration and the private sector. Within the DC National Assembly 
delegation, 35 of 47 members have prior parliamentary experience; within the LCD delegation, six of twelve have such experience. Within the opposition ranks, only 24 of 55 members appear to have had prior experience in Parliament (Ambrose 2015a, pp. 18-20, 23, 30-33).

Mosisili's immediate decision to dismiss and demote Maaparankoe Mahao and reinstate Tlali Kamoli as LDF commander was far worse than the 'missed opportunity' noted by the US Ambassador. This dreadful beginning reinforced the spectre of lawlessness, which threatened Lesotho's eligibility for trade preferences under the US African Growth and Opportunity Act and for renewal of its Millennium Challenge grant, putting tens of thousand of jobs in jeopardy (Ntaote 2015c). Kamoli's reappointment was followed by the murder of a leading $A B C$ stalwart, the flight of the leaders of the ABC, BNP and RCL to South Africa in fear of their lives, and the arrest and torture by the LDF of officers associated with Mahao. This sorry tale culminated in the assassination of Maaparankoe Mahao by LDF personnel, who were allegedly trying to arrest him on the bizarre charge of 'plotting a mutiny' while he was the LDF commander (Mohloboli 2015d).

The widespread condemnation of Mahao's death, globally, in southern Africa, and by most elements of civil society in Lesotho, has created a renewed crisis and SADC intervention. Less noted but also questionable was the appointment of DC stalwart Monyane Moleleki as Minister of Police and Public Safety, given that he had yet to answer charges of corruption. To be sure, Moleleki's critics in the ABC and BNP had themselves politicised the police (Ntaote 2015b). But throwing the fox among the chickens was another odd way for the new coalition government to fulfil its promise to depoliticise the civil service and security forces. As a result, Police Commissioner Khothatso Tšooana also sought refuge in South Africa following Mahao's assassination.

\section{LINKAGES AMONG ELECTIONS, DEMOCRATISATION AND GOVERNANCE IN LESOTHO}

This evaluation of Lesotho's electoral trajectory includes six key elements, namely: 1) inclusiveness, 2) successive fair elections, 3) alternate power holders, 4) external interventions, 5) institutional problems, and 6) public perceptions.

Andrew Reynolds (1999, p. 268) argued that 'those [sub-Saharan African] countries with institutional mechanisms which create an atmosphere of inclusion are doing considerably better than those states that have opted for more exclusionary structures.' This perception seems validated by the disruptive consequences that followed Lesotho's 1993 and 1998 elections with their first-past-the-post system, where opposition parties were excluded from Parliament. However, the greater threat to stable and effective government and viable opposition in Lesotho now 
derives from too much inclusiveness, which has resulted from the proliferation of tiny parties with little pretence of broad national support.

To be sure, the current single-vote system puts smaller parties and independent candidates at a disadvantage (Commonwealth Observer Group 2012, p. 42). For example, if separate votes had been allowed for constituency candidates and parties, independent candidate Frisco Khomari would likely have won his seat in 2012. Voters could have supported him without having to desert their favoured party. Despite this disadvantage, four small parties - each gaining less than $1 \%$ of the 2015 vote - each received one proportional seat in the National Assembly. As Cabinet members, their leaders can actually determine the fate of the coalition government. Under a two-vote system, other tiny parties that did not field enough constituency candidates to qualify for compensatory proportional representation in 2012 and 2015 would likely have gained proportional seats. The result would have been even greater fragmentation in the National Assembly.

Many states that use the proportional representation system require a minimum threshold to gain representation; Lesotho has no such requirement. The rationale for such a threshold is to ensure that a party has a credible following and to prevent extreme fragmentation that may promote instability. A threshold of even $1 \%$ in Lesotho would encourage tiny parties and independents to make compromises before an election and to amalgamate with more viable parties that command a larger voice in national affairs. At this stage, creating a threshold is unlikely, because the leaders of five small parties have gained not only substantial parliamentary stipends but also the emoluments of ministerial posts. Moreover, those leaders' desire to sustain their newly-acquired power could enhance the durability of their otherwise vulnerable coalition. Their success will likely encourage other tiny parties to keep competing or even more to join the fray.

Deposits intended to deter frivolous candidacies are presently set at too low a level to achieve this objective. The fees are M200 (\$20) for a constituency candidate and M8 000 (\$800) for a party list. A party need gain only one constituency or proportional seat to avoid forfeiture. Few constituency candidates reach the required $10 \%$ of the vote, but the amount at risk is hardly onerous. Moreover, the IEC financed the 2012 and 2015 campaigns such that each registered party was entitled to a basic amount plus a substantial addition, which was calculated on the party's total vote in the prior election. ${ }^{3}$ Hence any disadvantage to smaller parties under the single-vote system is quite minimal - though the two-vote system would indeed serve small parties better.

3 Letsie (2013:70) seems not to have noticed the extra funding provided under a belated amendment to the electoral law in March 2012, so his data are incorrect. 
A greater potential problem for electoral finance relates to external contributions. These must be reported to the IEC if they exceed M200 000. Muammar Gaddafi allegedly supported the ABC campaign in 2007. Monyane Moleleki admitted that Nikuv, the Israeli corporation accused of corruption in the awarding of Lesotho's M292 million contract for identity documents, had contributed funds for the 2012 DC campaign.

Lesotho has had six successive free elections since returning to civilian rule in 1993, though some parties perceived the outcomes in 1993, 1998 and 2007 to be unfair. By contrast, Staffan Lindberg (2006, pp. 2-3, 84) argues that the 2002 poll under the new mixed member system was a 'first' or 'founding' election because of the 'breakdown' of the prior system in 1998. Using his logic, the 2012 election was a 'third' election where 'turnover' of the party in power, rare in African elections, becomes more likely (Lindberg 2006 p. 15). Lesotho's 2011 electoral reforms, which resolved the problems of 2007, seem to support Lindberg's (2006, p. 42) observation that such a turnover is facilitated when 'more experienced opposition and more international pressure' force incumbents 'to accept a more level playing field.' The 2015 election and the second transfer of power might seem to provide further validation of this view. Both the 2012 and 2015 elections met Lindberg's criteria for evaluating democratic elections. They were deemed free and fair, opposition parties participated readily, and the manager was an independent commission. Competition was intense. Only minor disruptions occurred, and the result was accepted by winners and losers alike (Lindberg 2006, pp. 2, 29-33, 100-101). The victories of DC in rural areas, which declined somewhat after that party lost access to government largess, support Lindberg's (2006, p. 12) observation that rural voters 'continue to choose representatives based on how good they are as "patrons" of their respective constituency.'

The 2002 election mirrored Lindberg's (2006, p. 146) view that 'First elections not only signify democracy; they breed democracy, through the self-reinforcing, self-improving quality of repetitive elections.' The 2007 controversy illustrates electoral problems caused by 'oligarchic tendencies' in political parties and by difficulties in managing and utilising power (Lindberg 2006, pp. 126, 130). Those who despair for Lesotho's democratic future after 2007 could learn from his assurance that useful networks can emerge from problematic elections: 'By testing the rules and even by breaking them, actors learn... and decide whether to agree and play by them or not' (Lindberg 2006, pp. 97, 125). Controversy created space for civil society and the media as well as non-governmental, regional, and international organisations to assist in altering the political perceptions and behaviour of both government and opposition parties.

Lindberg (2006) argues further that leaders make alternative calculations when electoral patterns are reiterated several times under a stable set of rules, rather 
than being a 'one shot' phenomenon. As in the game of the prisoner's dilemma, cooperative strategies emerge through repeated or prolonged encounters. Strategies of participants become 'mutually dependent on expectations of how others will behave' Lindberg (2006, pp. 109-110). In both 2012 and 2015, preelection agreements among the parties to abide by the results had been made publicly in the presence of prestigious brokers, including individuals, civil society groups and representatives of international organisations.

According to Lindberg (2006, p. 23), the willingness to turn over power is 'the ultimate indicator of [electoral] competitiveness'; such willingness provides 'unambiguous evidence that the election results have been accepted by the losing incumbents.' Moehler and Lindberg (2009, pp. 1451, 1463) endorse Samuel Huntington's 'two-turnover-test' as evidence of the consolidation of democracy. Repeated turnovers, they argue, narrow the gap between the winners' and losers' perceptions about electoral legitimacy. In addition, alternation in office helps to lessen corruption by rooting out the 'rascals' (Lindberg 2006, p. 152). But in counties like Lesotho with a weak economy and politicised civil service, losing power means losing access to wealth and other perquisites of office, which augments the stakes of electoral success. Yet Lesotho has now experienced that crucial second turnover of power.

If the congruence between Lesotho's electoral trajectory and Lindberg's theory sounds too good to be true, it is. The special circumstances of Lesotho's geopolitical encapsulation within South Africa make it a unique case. The aptness of Lindberg's theory must be qualified by noting that Lesotho's second transfer of power occurred in the presence of both the South African president and vice president - and this only after a considerable period in which SADC monitors (dominated by South African personnel) had shaped events. Thabane had little choice. Without those external players, a military takeover or forcible ouster of Thabane in favour of Metsing or Mosisili might well have occurred. The four SADC post-election interventions since 1993 have affected political behaviour in Lesotho far more extensively than suggested by Lindberg's comment that regional and international 'pressure' creates 'space'. It is highly unlikely that Lindberg could have anticipated a newly-elected coalition government being held hostage by elements of the LDF and its appointee as commander.

During the post-election interventions by South Africa and SADC, almost all Lesotho's past and present leaders have, at one time or other, denounced South African interference with Lesotho's sovereignty. Nevertheless, the same leaders have not hesitated to call for assistance when their own power has been threatened, often asking for more extensive engagement than SADC and South Africa permitted. They have, perhaps unintentionally, drifted into a dependent mindset where they allow their political battles to push Lesotho to the brink of 
disaster, knowing that under SADC auspices, South Africa would bail them out to prevent having a failed state within its borders. King Letsie III's comment was wholly on the mark when he told Parliament that 'Lesotho should put its own house in order instead of expecting others to do it for us' (Ambrose 2014d, pp. 3-4).

Despite King Letsie III's sentiment, the fifth SADC intervention is now in progress. This intervention was necessary because of the flawed assumption of the previous mission that Lesotho's instability could be solved by a new election, without resolving the security crisis. SADC forensic teams and pathologists have investigated the circumstances of Maaparankoe Mahao's death. The report by Cyril Ramaphosa and an initial fact-finding mission to the Special SADC Summit on the Lesotho crisis, held on 3 July 2015, led to three important initiatives (Zihlangu 2015b). The Mosisili government has accepted a SADC Commission of Enquiry, chaired by Botswana High Court Judge Mpathi Phumaphi, to examine in depth what precipitated Mahao's death and, hopefully, the series of events which led up to it - including the August 2014 quasi-coup. A SADC Oversight Committee, consisting of two politicians, two military officers, two police officers and two intelligence officers was established 'as an early warning mechanism' to head off further instability; and if necessary, to 'intervene in consultation with SADC Facilitator Cyril Ramaphosa'. Finally, SADC will try to promote 'a conducive environment for the safe return of Lesotho's three exiled opposition leaders' Zihlangu 2015b).

The worst missed opportunity occurred when chaos in Lesotho early in the post-apartheid era precluded vigorous efforts to work out a new socioeconomic relationship with South Africa (Weisfelder 1997). More recently, the South African past and current presidents, Mbeki and Zuma, have opted for the lower-cost palliatives of successive coercive interventions. Both Mbeki and Zuma have avoided addressing the more challenging issue, namely that Lesotho's geopolitical situation demands the negotiation of a special dispensation. Lesotho requires a unique relationship with South Africa, one that would be distinctive compared with South Africa's relationships with other SADC states.

Barring the unlikely merger of either $\mathrm{ABC}$ or DC with their smaller partners, or the even less probable setting of a minimum threshold for representation, coalition governments with small majorities seem to have eclipsed the prior dominant party pattern. Nqosa Mahao ${ }^{4}$ has argued that only a grand coalition of the major parties could provide the 'inclusivity and focus on national healing' needed to end the current impasse, make necessary reforms, and bring a modicum of political stability (cited in Ntaote 2015a). Given the shared origins of ABC,

4 Nqosa Mahao is Vice Chancellor of the National University of Lesotho and brother of the late Maaparankoe Mahao. 
DC and LCD and the absence of any ethnic, cultural, linguistic, religious or even significant policy differences among them, such a dénouement might seem feasible. However, their legacy of bitter personal rivalries and their propensity to share the spoils of office narrowly have created great barriers to a consensual outcome.

A more modest route to stability may lie in the enactment of institutional reforms outlined in two reports issued by Commonwealth envoy Rajen Prasad (2014a \& 2014b). Prasad's reports were issued after the 2014 New Zealand visit by the Lesotho parliamentary delegation. Because partisan appointments within the civil and security services became a major source of conflict, Prasad urged the reestablishment of an independent professional civil service. He suggested that Parliament make changes appropriate to the mixed member environment, including requirements to lessen the destabilising effects of members 'crossing the aisle' to another party. He recommended returning to the previous two-ballot electoral system. Without there being any thresholds for representation, and with minimal deposits, public funding, and high returns from winning even one parliamentary seat, one wonders if this slightly more inclusive method would be a step in the right direction.

Prasad's main focus was the urgent need for a standardised set of rules and procedures for creating and maintaining a governing coalition. He listed seventeen points to be considered in negotiating a coalition, and fourteen elements that are typically included in coalition agreements. These essentials include 1) statements about shared values, goals and policy objectives; 2 ) clauses on consultation, management, and dispute resolution; and 3) provisions permitting parties to maintain separate identities and the ability to 'agree to disagree'. A final essential feature was transparency, so the public can ascertain the structure and programmatic objectives of the new government. The coalition agreement that was formally signed and published in April 2015 included almost all these elements (Ambrose 2015b, pp. 6-9). However, prospects for coherent, effective and stable coalition government in Lesotho have been dimmed by Mosisili's having purged Thabane's appointees from the top ranks of civil and security forces - well ahead of the enactment of promised reforms to restore criteria for professionalism, merit and transparency (Mohoboli 2015c; Mokheti 2015).

Public perceptions are vital to the success of Lesotho's mixed member electoral system and its ability to promote effective democratic governance. Moehler (2013, p. 223) found a gap in support for democratic institutions between electoral winners and losers that often narrowed when power changed hands. Winners were frequently too willing to accept undemocratic constraints. They could become as problematic as disgruntled losers who didn't hesitate to destabilise the political system. Cho and Bratton (2005, p. 9) showed that the gap in 'satisfaction 
with democracy' between winners and losers had narrowed in Lesotho after the mixed member system replaced the first-past-the-post system. A comparison of Afrobarometer survey data on 'support for democracy' from 2006, 2008, and 2012 respectively showed a decline in public support after the controversial 2007 election, and higher levels of support after the widely accepted 2012 election and resultant transfer of power. Compared with 2007, far more people who were interviewed in 2012 said that Lesotho was a democracy (Afrobarometer 2013a, pp. 6-7). Trust in most government institutions had increased, while perceptions of corruption had declined (Afrobarometer 2013b, pp. 2,4).

However, the Afrobarometer data also showed that polarisation persisted: $36 \%$ of people who were interviewed agreed that Tom Thabane was doing a good job, 32\% disagreed, and the remainder were undecided. Most likely the recent turmoil may have lessened Basotho confidence in government effectiveness and public support for democracy. A survey of popular reactions to Prasad's findings provides further insight (Report of the Community Voices Project 2014, p. 22). Respondents affirmed most of Prasad's recommendations, and supported greater public accountability regarding the processes of coalition formation and operation. On a key question, $56 \%$ of respondents preferred single-party over coalition rule, suggesting that people were concerned about the failure of the first coalition to address their needs.

All in all, the mixed member electoral system has served Lesotho well. Variations of this system have been used since 2002, and appeared in slightly revised form in the 2012 and 2015 elections. The system has permitted a wide range of parties and individuals to participate and to have a realistic chance of gaining representation, though low voter turnout remains a problem. The issue needing attention is whether the present system can create stable and effective majority or coalition governments, and a coherent opposition that is able to articulate alternatives and assume power if called upon. A system with reasonable minimum thresholds for representation could provide the electorate with greater influence over the composition of the government. In 2015, the likely composition of various possible coalition governments was known in advance. But the more fragmented the political party system becomes, the more discretion party leaders gain in determining who will govern.

In both 2012 and 2015, the 40-member proportional component ensured that the composition of the National Assembly closely paralleled the national distribution of partisan support. Unlike South Africa's completely proportional system, citizens of Lesotho had a specific Member of Parliament from their area to contact or hold accountable. Party bosses use the composition and ranking of party lists to determine who will likely become proportional members and therefore command their loyalty. By contrast, constituency members have greater 
independence because they typically require local support to win nomination. To be sure, there are many complaints that, once elected, even constituency members fail to report back sufficiently. Nevertheless, the present system permits a remarkable balance between the direct accountability of some parliamentarians to citizens, on the one hand; and, on the other, the composition of the legislature commensurate with national levels of support for various parties. It has provided an effective remedy to the exclusionary results of the first-past-the-post system. However, the current system has yet to demonstrate that it can promote better governance, greater accountability, and stronger commitment to democratic values. Unfortunately, intimations that the Mosisili administration may be hostage to a renegade military clique do not bode well. Hopefully the renewed SADC intervention and threatened loss of external assistance will compel the Mosisili coalition to reassert civilian supremacy and engage with the opposition in a substantive programme of reform.

\section{- REFERENCES -}

Afrobarometer 2013a 'Basotho have increased their support for democracy', http:/ / www.afrobarometer.org/files/documents/media_briefing/les_r5_ presentation6.pdf

Afrobarometer 2013b 'Basotho trust in opposition parties rises', http://www. afrobarometer.org/files / documents / press_release/les_r5_pr3.pdf

Ambrose DP, 2009-2015, Summary of Events in Lesotho, a quarterly publication compiled and written by David Ambrose, published by House 9 Publications \& Mohokare Trust. Address: Box 958, Ladybrand 9745, South Africa. The following issues were referred to:

$2009,16(3)$.

2012a, 19(2).

2012b, 19(3).

2013, 20(3).

2014a, 21(1).

2014b, 21(3).

2014c, 21(4).

2015a, 22(1)

2015b, 22(2).

Bame, P 2009, 'Masire blames Lesotho government for unrest', Mmegi, 23 July, http: / / www.mmegi.bw / index.php?sid=1\&aid=7\&dir=2009/ july / thursday23.

Chimombe, B 2014, 'Zuma attempts to intervene in Lesotho political stalemate', SABC News, 29 July, http://www.sabc.co.za/news/ 
a / 2547bb0044e868a9833a93a5ad025b24 / Zuma-attempts-to-intervene-inLesotho-political-stalemate-20140729

Cho, W \& Bratton, M 2005, 'Electoral institutions, partisan status, and political support: a natural experiment from Lesotho', Afrobarometer Working Paper No. 49, Michigan State University.

Commonwealth Observer Group: 'Lesotho Parliamentary Elections - 26 May (2012)' report, Commonwealth Secretariat. i-v, pp. 1-46, London.

Election Special: Insight section, 2015, The Post, 13 January, pp. 1-18

Elklit, J 2008, 'The 2007 general election in Lesotho: abuse of the MMP system?', Journal of African Elections 7(1), pp. 10-19.

Independent Electoral Commission of Lesotho 2015, 'National Assembly Election 2015 - Results', http: / /www.iec.org.ls /

Interim Mission Statement 2015, SADC Parliamentary Forum Election Observation Mission to the 2015 Lesotho National Assembly Elections, SADC Secretariat, 2 March, Gaborone.

Koloi, B 2014a, 'Coalition parties represented in IEC', Lesotho Times, 12 January, http:/ / lestimes.com/ coalition-parties-represented-in-iec/

Koloi, B 2014b, 'Metsing condemns dismissal of DC supporters from civil service', Lesotho Times, 9 May, http:/ / lestimes.com/ ?p=16371

Koloi, B 2015, 'Lesotho not ready for elections - IEC boss' Lesotho Times. 15 January, http:/ / lestimes.com/ lesotho-not-ready-for-elections-iec-boss /

Lesotho Times 2011, 'Billy reacts angrily to reports that he was sacked', 17 November, http:/ / lestimes.com/?p=7649.

Lesotho Times 24 October 2013 'Thabane, Tsekoa Clash', http://lestimes. $\mathrm{com} / \mathrm{p}=13924$

Letsie, TW 2013, 'The 2012 general elections in Lesotho: a step towards the consolidation of democracy', Journal of African Elections, 12(1), pp. 65-83.

Likoti, FJ 2009, 'The 2007 general election in Lesotho: The application and the challenges of the electoral system', African Studies Quarterly, 10(4), pp. 57-69.

Lindberg, SI 2006, Democracy and elections in Africa, Johns Hopkins University Press, Baltimore.

Makoa, FK 2008, 'Party alliances and political coalitions during the 2007 general election in Lesotho', Journal of African Elections. 7(1), pp. 50-65.

Masire, K 2009, 'Report on mission to Lesotho as eminent person designated by SADC', Lesotho Times, 16 July, reprinted in Ambrose (2009:11-12).

Matlosa, K 2008, 'The Lesotho general election of 2007: managing the post-election conflict', Journal of African Elections. 7(1), pp. 20-49

Moehler, DC \& Lindberg, SI 2009, 'Narrowing the legitimacy gap: turnovers as a cause of democratic consolidation', The Journal of Politics, 71(4), pp. 1448-1466.

Moehler, DC 2013, 'Critical citizens and submissive subjects: election losers and 
winners in Africa' in Voting and democratic citizenship in Africa, in M. Bratton (ed), Lynne Rienner Publishers, Boulder CO / London, pp. 219-238.

Mohloboli, K 2015a. 'Mosisili vows to avoid Thabane's "blunders"', Lesotho Times, 12 March, http: / / lestimes.com/mosisili-vows-to-avoid-thabanes-blunders / Mohloboli, K2015b, 'Mosisili in cabinet dilemma', Lesotho Times, 19 March, http:/ / lestimes.com/mosisili-in-cabinet-dilemma

Mohloboli, K 2015c, 'Six principal secretaries sent home', Lesotho Times, 25 June, http:/ / lestimes.com/ six-principal-secretaries-sent-home/

Mohloboli, K 2015d, 'Mahao's last moments', Sunday Express, 28 June, http:/ / sundayexpress.co.ls / mahaos-last-moments /

Mokhethi, S2015, ‘Parliament reforms under threat' Public Eye, 8 May, http: / / www. publiceyenews.com/site/2015/05/08/ parliament-reforms-under-threat/

Ntaote, B 2012, 'Mosisili angers coalition', Lesotho Times, 6 July [Deleted from site]. Ntaote, B 2014a, 'Explosive start to peace talks', Lesotho Times, 24 July, http:/ / lestimes.com/ explosive-start-to-peace-talks /

Ntaote, B 2014b, 'Mosisili urges Thabane to do "the honourable thing"', Lesotho Times, 18 September, http:/ / lestimes.com/mosisili-urges-thabanehonourable-thing/

Ntaote, B 2014c, “"Foreign” police presence angers MPs', Lesotho Times, 23 October, http: / / lestimes.com / foreign-police-presence-angers-mps /

Ntaote, B 2014d, 'LCD hails Ramaphosa Mediation', Sunday Express, 26 October, http: / / sundayexpress.co.ls/lcd-hails-ramaphosa-mediation/

Ntaote, B 2015a, 'Mahao calls for grand coalition', Lesotho Times, 5 March, http: / / lestimes.com/mahao-calls-for-grand-coalition/

Ntaote, B 2015b, "Maseribane warns of "security crisis"', Lesotho Times, 23 April, http: / / lestimes.com/maseribane-warns-of-security-crisis /

Ntaote, B 2015c, 'America slams Kamoli return', Lesotho Times, 28 May, http:/ / lestimes.com/america-slams-kamoli-return/

Prasad, R 2014a, 'Governance in Lesotho: repositioning for success, The Commonwealth, London.

Prasad, R 2014b, Working towards a sustainable democracy in Lesotho, The Commonwealth, London.

Report of the community voices project on the New Zealand report, sponsored by Development for Peace Education, Action Aid and MoAfrika FM and funded by Denmark Lesotho Network, pp. 1-38 (esp. p. 22).

Reynolds, A 1999, Electoral systems and democratization in Southern Africa. Oxford University Press, Oxford / NY.

Rosenberg, S \& Weisfelder, RF 2013, Historical Dictionary of Lesotho (2nd ed), Scarecrow Press, Toronto / Plymouth.

Southall, R 2003, 'An unlikely success: South Africa and Lesotho's election of 2002', 
Journal of Modern African Studies, 41(2), pp. 269-296.

Sunday Express 2013, 'Coalition under siege', 14 September, http:/ / sundayexpress. co.ls / coalition-under-siege

Tefo, T 2014, 'Metsing angry over corruption charge' Sunday Express, 4 August, http:/ / sundayexpress.co.ls/?p=11839

Weisfelder, RF 1997, 'Why Lesotho needs a distinctive diplomatic strategy, but hasn't found an appropriate format', Africa Insight, 27(1), pp. 32-43.

Weisfelder, RF 1999, 'Why fair elections get fouled in Lesotho: a search for solutions', Journal of African Policy Studies, 5(2\&3), pp. 109-132.

Weisfelder, RF 2001, 'What is delaying elections in Lesotho?' South African Journal of International Affairs, 8(1), pp. 75-81.

Weisfelder, RF 2014, 'Lesotho's interactions with South Africa and regional organizations', South African Journal of International Affairs, 21(1), pp. 109-129.

Zihlangu, B 2013, 'Thabane unveils coalition's policy blueprint', Lesotho Times, 7 March, http: / / lestimes.com/?p=11634

Zihlangu, B 2014, 'Thabane feeling threatened', Lesotho Times, 13 June, http:/ / lestimes.com $/ ? \mathrm{p}=16683$

Zihlangu, B 2015a, “"Deadwood” debate rages on', Lesotho Times, 12 March, http: / / lestimes.com/deadwood-debate-rages-on/

Zihlangu, B 2015b, 'SADC resolutions on Lesotho', Sunday Express, 5 July, http: / / sundayexpress.co.ls/sadc-resolutions-on-lesotho/

Zihlangu, B \& Ntaote, B 2014, 'Coalition pact collapses', Lesotho Times, 13 June, http:/ / lestimes.com/?p=16706 